\title{
The Overdesigned and the Undesigned - Placemaking in New Residential Complexes
}

\author{
Marie Stender, \\ The Royal Danish Academy of Arts, School of Design \& The Danish Building Research Institute, Aalborg \\ University
}

\begin{abstract}
This article focuses on the paradox that places on the one hand are increasingly regarded as something that can be designed, while these designed places on the other hand also seem to hold a remarkable longing for that which is not designed. Inherent in contemporary concepts like urban design, city branding, and placemaking is the assumption that we can - and should - design not only our material surroundings but also the more immaterial social and cultural aspects that constitute a place. In her book Brandscapes, American architect Anna Klingmann argues that the focus of architecture in the experience economy has evolved from "what it has" and "what it does" to "what you feel" and "who you are" (Klingmann, 2007). But by what means and to what extent is it possible to design how we feel and who we are? I address these questions by focusing on how place is designed when new residential complexes are given shape and taken into use.
\end{abstract}

Keywords: urban design, place branding, experience economy, housing market, Anthropocene

\section{INTRODUCTION: HOW PLACES COME ALIVE}

Welcome to the boot camp of the 8-house. Here we work to create life in the house. Come inside if you want to hear more about the possibilities in "the modern mountain village"...

The invitation is printed on the window pane of the ground floor of the 8-house. But why call a new residential complex in Copenhagen "a modern mountain village"? And how is "life" created in a new place like this?

Houses and urban spaces have traditionally been considered as belonging to the domain of architects rather than that of designers, and the division between the two professions is still often held to be a matter of scale: Architects deal with cities and houses, designers with interiors, furniture, and smaller articles for everyday use. However, it is the broader notion of design that I am concerned with here, and in this context the design of places is worthwhile scrutinizing, exactly because it illustrates the growing prevalence of design thinking. Today the practice of design no longer limits itself to the world of small things or even to the world of things. Immaterial issues, cultural processes, and complex social problems are handled and conceived within the tools and vocabulary of design. It is not just architecture that is designed for given places; places are also designed in order to make them come alive.

In this article, I explore how place is designed based on ethnographic fieldwork ${ }^{1}$ among residents, architects, planners, developers and real estate dealers in two new residential complexes in the Copenhagen region. I have retrospectively traced how these new places have taken form and meaning in the process from drawing table to occupancy. During the fieldwork, I realized that although my cases can be seen as thoroughly designed or even over-designed environments, they are not just shaped by the people who design, build, sell, and use them. Unplanned and uncontrollable factors like the 2008 financial crisis have also left significant traces in their material and social fabric. In order to understand how places - and other things - are shaped, we therefore have to take into account the fluctuations of the market. In the first part of this article, I outline a brief biography of the two cases, the 8-house and the A-house. Then I analyze how not only their built environment, but also their identity, story and social life have been designed. Eventually, I focus on the traces that the financial crisis have left in my cases and discuss how we can understand the design of places in what I - inspired by the French anthropologist Bruno Latour - characterize as the age of the Anthropocene (Latour, 2011). 


\section{DESIGNED PLACES - 2 CASES}

\section{The A-house: New York lofts for a cosmopolitan creative class}

Situated in Copenhagen's harbor area, the house with the shape of an A was originally built in 1963 for industrial use. Later on, it was used as an archive for The Danish Broadcasting Company and the Danish Postal Service, but was also left empty for several years. When the developer purchased the building with the goal of turning it into exclusive loft apartments, the refurbishment process had to wait for a couple of years while the City of Copenhagen completed the district plan. In the meantime the new building owner decided to sublet the worn-out building to studios for artists and creatives. In an interview, the architect in charge of the refurbishment, Carsten Holgaard, explains that this was partly to act as a patron for the cultural life of the city, but also to provide the building with a history and creative aura, to hype the place and change most Copenhageners' view of this area as being on the outskirts of the city. ${ }^{2}$

For a couple of years, the A-house served as a hub for underground artists. Parties were held here, music videos recorded and several artists that have later on become well established had their studios in the house. In 2006-10 the house was refurbished and converted into 180 New York-style loft apartments, tearing down and replacing everything but the concrete skeleton. In various places, the artists had painted on concrete pillars and walls, and their traces and marks were preserved and integrated in the décor of some of the loft-style apartments. Furthermore, the building owner funded the printing of a coffee table book documenting the creative life of the house in aesthetic photographs and texts describing the magic of temporary creative spaces. Before the refurbishment was completed, however, the financial crisis had hit the Danish housing market, and it became difficult to sell private apartments. The building owner decided to change the house into service apartments and opened an apartment hotel with the name STAY. In December 2009 all apartments were sublet for the COP15 summit held in Copenhagen, and this financed the furnishing of the whole house by the Danish design company HAY. "STAY - touched by HAY" says the slogan printed on the windowpane of the reception, which welcomes residents with a minimalist black and white décor and elaborate flower decorations. Apart from the reception, the ground floor also houses a bakery, a hairdresser, a restaurant, and a sushi restaurant, all handpicked by the developer to cater for the residents of the A-house. Today the house has the status of something in-between a design hotel and a more permanent home for its residents: A few apartments have been sold, some are occupied by residents who need a temporary home, while the majority of the apartments are occupied by international people who are temporarily in Copenhagen on business purposes.

\section{The 8-house: A modern mountain village}

The 8-house was finished in 2010 and consists of 476 townhouses, apartments and penthouses integrated in one giant building with the shape of the figure eight. A one kilometer long pathway winds up along the facades making it possible to walk - or even bicycle - to the top of the building and enjoy the view of the surrounding vast green area. The 8-house is located on the outskirts of the new urban district of Ørestad, bordering the 2000 acres of Amager Commons.

Besides this, the branding highlights that the building was designed by the internationally acclaimed Danish architecture firm BIG (Bjarke Ingels Group), and that the apartments - apart from all the usual amenities of a modern home - include charming details such as skewed angles and varying floor-to-ceiling heights. The architect has on various occasions described the project as a modern mountain village, and the metaphor is also used on the website:

The pathway is planned as a natural meeting place for the residents of the house and as a safe thoroughfare for children visiting one another. As an extra bonus, it creates a very charming way to move about within the building complex. Like living in a mountain village where one moves in a rolling landscape and every now and then just has to stop to enjoy the tremendous views of all four corners of the world! ${ }^{3}$

In order to ensure a vibrant atmosphere from the beginning, the building owner financed the running of a café that opened long before there were enough customers in the area, and a temporary gallery exhibiting 8 young artists from 8 European art academies. The real estate agent explained to me: "We had to do something to get people out there, and to show them that there can actually be city life in Ørestad". The apartments represent a broad range of sizes and price-levels, and the residents are consequently quite diverse both in terms of age and social and cultural backgrounds. In the center of the 8-house there is a common room, and the developer launched a special intranet called 8-book in order to facilitate the residents' communication. In retrospect, however, he says he shot himself in the foot, as the intranet is now used not only to organize social gatherings but also to mobilize residents against shoddy construction work and to discuss how to deal with the massive groups of architectural tourists and other visitors climbing 
the pathway in order to explore the spectacular building. The public interest has increased after the building was awarded numerous Danish and international architecture prizes and according to some of the residents, the architect has several times been photographed by the press bicycling on the pathway of the house.

\section{CITY LIFE AS IMAGE}

At the outset of my fieldwork, I supposed that although these new places had an appearance of being explicitly designed from the outset, their meaning would be created and altered over time through residents' everyday use. In this I was inspired by French philosopher Michel de Certeau's distinction between the urban designer's view of the city from above and the pedestrian's everyday appropriation of urban space (de Certeau, 1990, p. 97). Architects, urban designers, and developers might shape the physical space, but it would be up to the users to make the place come alive. However, as the two biographies above illustrate, the everyday life and activities taking place in the buildings do not just evolve among users after occupancy; rather it is carefully staged and designed alongside with the places' architectural design. In the A-house, artists and creatives were involved in putting the place on Copenhageners' mental city-map and imbue the building with a creative aura. In the 8-house, the developer had musicians give concerts in the café and young artists exhibiting in the temporary gallery long before all the apartments were sold. In both cases, artists and other creatives were strategically involved in hyping the place to enhance its commercial value.

In urban planning, gentrification is when rents in formerly worn-down neighborhoods rise and middle class residents gradually replace less affluent groups. As demonstrated by American sociologist Sharon Zukin in her study of loft living in New York, artists and creatives often play an important role in these gentrifying processes (Zukin, 1989). The low rents and rough charm that attract the creatives may thus be changed by their very presence, as they render the place more attractive for investors and wealthier residents. In the A-house, however, the investors came before the artists, contacted them and offered lowered rents in order to shape the place according to their ideas. This process of designed gentrification is currently seen in many other places and is often linked to the transformation of industrial buildings into trendy housing mixed with workspaces, a combination that emphasizes stylish elements of industrial architecture and has been labeled "Industrial Cool" (Willem, 2006).
In the 8-house there was neither an industrial building to refurbish, nor a worn-down neighborhood to gentrify, but here also artists and creatives were used as a strategic resource to kick-start urban life. The belief in creative groups as a catalyst in urban transformation is closely connected to Richard Florida's theory of the creative class (Florida, 2002) that was highly influential on Scandinavian planning and politics in the beginning of the new millennium. Florida argued that bohemians like artists and musicians were key to attract the broader creative class, but also stressed the importance of cultural activities, vibrant street life and authentic urban environments (ibid., p. 231). This logic is likewise reflected in the design of city-life in my cases. The selection of shops and functions of the ground floor in the two buildings were thus neither left to market forces, nor based on a first-come-first-served principle, but rather designed to ensure the right feeling of city life. As the developer of the A-house told me: "We had to be very patient because we didn't want a kiosk or a pizzeria, though there were many inquiries from them. We wanted some French, Italian and Asian takeaway, and a place where you can have breakfast, and a place where you can have your hair done".

In the 8-house, the building owner financed the running of the café for the first 6 months and a small delicacy-shop was handpicked. "Now we have both an inn and a grocer in the mountain village" the advertisement claimed, leaning heavily on the village metaphors. ${ }^{4}$ Even within the apartments, the visible characteristics of the everyday life post occupancy were staged, as the brand-manager of the house went to IKEA and bought 125 standard lamps that were lit in the empty apartments on Sundays before the real estate dealer's showings. "With time, life will come (...) but until then, we will have to help people's imagination", he explained to me.

My mission here is neither to criticize nor to promote the strategies applied in the two cases. Rather, I am interested in illustrating how images of urban life (the New York loft and the Mediterranean mountain village), sales strategies, social dynamics like gentrification, and design techniques interplay when places are shaped. The various attempts to make the 8-house and the A-house appear as vibrant places already before they were occupied resemble the renderings that are often used as sales material in a project sale where the apartments are sold before the complex is built. Elsewhere, I have argued that such computer generated images of new buildings and their environment in a project sale have great influence on the residents' conception of the place where they are about to move in (Stender, 2006, p. 
11). Just like the renderings, the staged city life in the 8 -house and the A-house outline a vision of how the place will develop in the future. Here, the vision is not just on paper, but conjured up live and in full scale. The apartments are not sold before they are built, but they are supposed to be sold before the desired city life evolves. The popular notion of city life is here not a description of the activities and patterns of use that gradually evolve in a place, but rather an image - in the shape of cafés, shops and galleries - that is strategically projected onto the place in order to make it evolve in a certain way.

According to de Certeau, the urban designer like the cartographer sees the city from above and "makes the complexity of the city readable, and immobilizes its opaque mobility in a transparent text" (de Certeau, 1990, p. 92). As the two cases illustrate, however, we can hardly uphold a clear distinction between the planned and readable space on the one side and the complex spaces of everyday life on the other. In current urban design, there is an increasing focus on creating what Swedish ethnologist Orvar Löfgren terms "elusive cityness," that is "the liquid uncontrollable flow and friction of everyday life" (Löfgren, 2007, p. 80). As Löfgren argues, "there has been a change from earlier modernist, urban ideals of the city with its high tempo and frictionless flow as a machine for living and transport logistics, to a focus on motion and emotion, intensity and experience" (ibid., p. 81). When architects, planners, and developers seek to invoke such a sense of elusive cityness in new urban areas, a crucial aspect is to design what seems undesigned.

\section{DESIGNING THE UNDESIGNED}

The former A-House was once a hub for Copenhagen's creative elite before being converted to the most recent urban hotel and serviced complex in CPH. This has been brought directly into the new STAY concept - from the architectural planning to the many collaborations with local artists who have left their mark on the apartments. The need for space has been woven into the design of every floor and the possibilities for the use of this space are many (...) The creative past of the A-House emanates from the countless artistic decorations that were never removed from the walls and ceilings. STAY has, quite simply, chosen to let them stay". ${ }^{5}$

On STAY's website, the creative past of the A-house is described as something that was prior to and therefore gave shape to the place as it is today: The artists and their use of the space has been "woven into" and "left their mark on" the design of the building.
When I talked to residents and artists in the A-house about the place's story, most of them were unaware that it was initiated by the building owner. In order to work its magic, the creative past must appear to be what gives shape to the present residential complex, although in actual fact, one could argue that it is the other way around. The paradox is that what is intentionally designed in these new places has to appear not to be designed.

Likewise in the 8-house, where the notion of the mountain village materializes in some rather irregular spaces. During my fieldwork, residents would often entertain each other and the visiting ethnographer with anecdotes of the strange spaces one could find in the 8-house. In one apartment, you would have to bend down to get out on the balcony, and another had what one resident laughingly described as a built-in doghouse: a room with only 1,5 meters from floor to ceiling. The architect Bjarke Ingels explained that in the design process he was inspired by a mountain village in Spain where people had accommodated themselves to the mountain slope as well as they could: "The result was some very charming and strange spaces where you suddenly had a big rock sticking out of the wall. They couldn't get rid of that, so instead they just painted it white. We have tried to create some of that same feeling in the 8-house. A mountain village with paths, stairways and bridges, with more quirky spatialities of a smaller scale. (...) In the mountain village there are no architects, people have made rooms for themselves, and sometimes the mountain is just stronger than the construction workers".

Denmark, and in particular the reclaimed land of Ørestad, has a very flat countryside, and the mountain-like shape of the 8-house has no relation to the topography of the place. In contrast to the absence of an architect in the Mediterranean mountain village, the architect appears to be quite present in the 8-house - even after the completion of the building. Nevertheless, it seems important for the architect to stress the undesigned character of the 8-house's quirky spaces. As one of the architects at the BIG office puts it: "One of the places that work really well in this building is up in the corner where you have one path and then it meets another one and it turns twice and the space there resembles what you see on a mountain in Spain (...). For once there is something in Danish architecture that you don't just understand right away (...). Not that we have tried to make a place that is fun or charming or cozy. We did not incline our heads and say: 'Now it's nice'. It was just a question of geometry: we had to break the system and introduce another one". 
The system that generates the shape of the path is of course a design technique, but it serves the same means as the mountain slope or the creative past. The place apparently gets into character when something undesigned gives it form and friction - even if these frictions are also designed. The paradox can be said to lie in the tension between the particular and the generic, as Löfgren argues: "Although the logic of city branding draws heavily on a 'generic toolkit' for building a platform, this process also centers on the production of difference, a unique 'spirit of place', a special atmosphere and a particular aura" (Löfgren, 2007, p. 81). What is sought designed in the 8 -house and A-house is this unique "spirit of place", but if it appears too designed it could as well be anywhere. In order to turn it into a place, something particular is needed, something that gives friction and shape to the surroundings, something that cannot be moved. In designing a place with charm and identity, an element of something undesigned is key - and consequently this element is designed as well.

\section{LIVING IN A BRANDSCAPE}

So far I have mainly focused on the place-making processes in architecture, branding, and designed city-life, but at this point it is essential to ask what happens once people move in and turn these designed places into the spaces of their everyday life? During the month that I lived in the 8-house as part of my fieldwork, I found that the notion of the mountain village had taken on a life of its own among the residents. Whereas at the beginning, some residents considered it merely part of a sales pitch, they were now themselves referring to the place as a mountain village, and one resident even opened a workshop in the basement and called himself "the village blacksmith". This did not just refer to BIG's story of the mountain village, but also to his own father who was a blacksmith in the village where he grew up, he told me. Residents move into a story and a brand as much as a building, but the prefabricated images are appropriated and molded to fit people's personal experiences and backgrounds.

Anna Klingmann sees branding as a means of transforming how people perceive and experience architecture, and introduces the notion of brandscapes to suggest that "architecture can play a critical role as a catalyst to generate an authentic identity for people and places" (Klingmann, 2007, p. 3). Though I am critical towards her notion of authentic identity, I find the concept of brandscapes useful here, as architectural design, branding, visual communication and experience design in my two cases blend together, forming powerful identity icons. Seen from above, the two buildings constitute simple, logo-like characters - the 8 , the $A$ - that are also integrated in their names, visual identity, on websites, graphic signboards and floor plans. The 8 and the $A$ seem to be architectural icons designed to be seen from Google Earth or in architectural magazines as much as from the other side of the street. ${ }^{6}$ The architecture of these designed places is not only frequently photographed for architectural magazines; the residents of the 8-house themselves also decorate both their private homes and communal rooms with photographs of the building. The iconic architecture seems to hold a lot of identity for them, and in Ørestad, where the 8-house is located, residents generally refer to the place they live by the building names - the 8-house, the Gatehouse, etc. rather than by the street names (Skovmand, 2011).

Just as the residents adopt the story of the mountain village, they adopt and make use of these icons in various ways. For instance, in the 8-house, the kindergarten located on the ground floor has chosen to use the 8-figure as its logo, and the building's characteristically angular shaped 8-figure is printed on the back of ring binders in the office as well as on the back of snowsuits worn by the nursery staff in winter. Klingmann argues that brandscapes shape the way people experience their surroundings, but it is tempting here to draw an analogy to the original meaning of the term brand: to "mark permanently with a hot iron", i.e., to burn the mark of the producer onto their products (Oxford Dictionaries, 2015).

The brand is of course not imposed on the residents, and some of them are not at all preoccupied with the village-metaphor. To them, the house is just a place to live, offering a nice and affordable apartment with a good view. Most of them nevertheless make use of the social medium called 8-book that was designed especially for the 8-house. Here, residents can exchange practical information and announce social activities. But the virtual spaces are much more than electronic notice boards; in terms of community-building and place-making, they seem to be even more important than the common rooms and facilities of the physical spaces. In combination with the prevalence of smartphones that allow people to update themselves continuously, the virtual space extends the social space of the built complex to a free-floating community where neighbors can constantly be in touch. Though emails are not always read carefully, the subject lines alone - "Wine-tasting tonight" or "Is there an electrician in the 8-house?" - provide residents with constant impressions of each other's doings. Though conceived as primarily a practical tool, the virtual fora are also where the social identity of the place and its residents is negotiated. A 
common lingo thus gradually develops, and here the brand and iconic shape of the built complex blend into the way residents address one another and name social activities. They refer to "the village" or integrate the number 8 in various linguistic inventions, such as the photo-club called "Aperture 8" (for research on the creation of an online group identity by the use of a group-specific language, see Haythornthwaite, 2007, p. 124).

So as to the question of whether it is possible to design "who we are" and "how we feel", one must say that the brandscape of the 8-house serves as a powerful icon for community-building and place-making among the residents. However, it is important to stress that the residents do not passively overtake the brand, but appropriate it and turn it into their own story just like they turn the built environment into their home. I do agree with Löfgren who claims that, in spite of the current focus on designing experiencescapes, people's experiences of their built surroundings - what he calls "the soft city" - cannot be designed: "As a person starts using the city, (...) the setting will gradually turn into a soft experience which may also create shared experiences, routines, rhythms and perceptions. But a soft city cannot be prefabricated. An experiencescape can only be created by those who use a certain setting and these patterns of usage may often conflict to produce bad, good, trivial or indifferent experiences" (Löfgren, 2007, p. 96). However, other uncontrollable factors might intervene in the way an experiencescape develops.

\section{AND THEN THE CRISIS CAME...}

Though the A-house is just as thoroughly designed a place as the 8-house, only a few of the residents there have adopted the brand and are familiar with the story of its creative past. Due to the $2008 \mathrm{fi}-$ nancial crisis, the character of the place changed several times during the refurbishment process. As Carsten Holgaard, architect of the A-house, puts it: "As to the economy, that's a world with a lot of turbulence. Suddenly the bank went bankrupt, the owner changed, and we figured we just had to be very willing to adapt, to make the best of the situation and get some quality into the place according to the situation". When the market for high-end private apartments vanished, Holgaard was thus actively involved in developing the idea of an apartment-hotel that, inspired by places in New York and Berlin, would offer temporary homes for the cosmopolitan creative class. He saw the serviced apartment concept as an opportunity to "design all the way", as he puts it and laughingly admits that this is the ultimate dream of any architect or designer: Instead of leaving the selection of kitchens and floorings to the future residents, every detail from furniture to fixtures and doorhandles in the entire house was selected and designed by Holgaard and his staff.

Though ownership of the building changed along the way, the vision of the apartment hotel was partly maintained, and today the front side which faces the waterfront has fancy furnished apartments and an exclusive reception and lobby. The other side of the house is rented out at cheaper rates and accommodates a much more diverse group. Here I met Indian software workers in Denmark on short-term contracts and various people in need of a temporary home. Some of them would complain to the reception about their apartments being unfinished. They did not associate the building's rough look and traces of the industrial and creative past with New York-style loft living, but rather just with poor finishing. During my fieldwork there, my neighbor turned out to be a Libyan military veteran who had lost a leg in the revolts against former Libyan leader Muammar Gaddafi. He was on a rehabilitation stay organized by the Danish International Development Agency, and some of his neighbors were quite alarmed about his one-legged appearance and parties at night. The house has indeed become home to a very global crowd, though in a much different way than the exclusive cosmopolitan vision anticipated in the initial design.

The crisis also left its marks on the 8-house, even if these were not as conspicuous as in the A-house. In the 8-house almost all apartments were sold, but this was only because the prices were dumped, construction work hurried up, and cost reductions pushed through on building costs and materials. It is beyond my field of expertise to decide whether this has had consequences for the quality of the building, but when some of the residents today experience their ceilings leaking water, they suspect it to be a consequence of the crisis. Whether talking to architects, residents, or developers, again and again during the fieldwork I would hear the phrase "and then the crisis came..." . This sentence points to all the things that differed from the plan, that which seems to be beyond control and impossible to design.

The locations of my fieldwork are not only shaped by thorough design processes, but also by the fluctuations of the market. According to French anthropologist Bruno Latour this might be seen as a mere condition of the age of the Anthropocene. This chronological term was first proposed by geologists to denote that human impact on the Earth's ecosystems is now so significant that it becomes relevant 
to talk about a new geological epoch. In Latour's wording, human beings can be considered a geological force: "We realize that the sublime has evaporated as soon as we are no longer taken as those puny humans overpowered by 'nature' but, on the contrary, as a collective giant that, in terms of terawatts, has scaled up so much that it has become the main geological force shaping the Earth" (Latour, 2011, p. 3). Even if the architect and residents of the 8-house might interpret the "mountain village" as being "overpowered by nature" to use Latour's words, what actually overpowers it is man-made: regulations and local planning processes, but also the turmoil of the market that seems more or less beyond control.

When I asked the architect Bjarke Ingels if it is really possible to design the kind of friction or undesigned charm that derives from the rock sticking out of the wall, he replied: “We don't have a mountain, but we have neighbors, different functions, and different needs: penthouses with a view, town houses that require a lot of social contact, and offices that need deeper space than the apartments. These are the things that decide the form". What the architect is skilfully orchestrating in the process of design can thus also be understood as the varying requirements of planning regulations and market demands. In developing a complex like the 8-house or the A-house the architect works in close collaboration with developers and real estate agents in modeling the place: What is the market for housing and offices right now? Does the market request penthouses or family housing? How tall is the building allowed to be? And how low should our square meter price be to be competitive right now? Hence, the friction that legitimates the form derives from market forces and man-made regulations of these rather than from topography or forces of nature. Though this kind of friction is not exactly considered to be as charming as that of the mountain slope (or in the A-house: the creative past), it can - to use Bjarke Ingel's words - definitely sometimes be stronger than the construction workers. In relation to the market forces, even architects, urban designers and powerful developers are no longer in control, but rather like de Certeau's pedestrians: "whose bodies follow the thicks and thins of an urban 'text' they write without being able to read it" (de Certeau, 1990, p. 93).

The notion of the Anthropocene is intriguing here because it concerns the way we shape the world unwillingly and in uncontrollable ways. Latour argues that the present ecological and economic crisis demonstrates that the earth is now finally round: "Of course we knew that before, and yet the earth's rotundity was theoretical, geographical, at best aesthetic.
Today it takes a new meaning because the consequences of our actions travel around the blue planet and come back to haunt us: It is not only Magellan's ship that is back but also our refuse, our toxic wastes and toxic loans, after several turns"(Latour, 2009, p. 144). Following Latour, our loans can be as toxic as our refuse, as both leave remarkable traces in the world we inhabit. We are responsible for both, yet they shape the world in ways that now seem beyond control: No one planned or designed the financial turmoil that left traces in my two cases; they can be seen as unintended design. While current placemaking processes seek to create a spirit of place by designing a kind of undesigned friction, a very different kind of market-related friction gives shape to the places we inhabit. Inherent in notions like placemaking and brandscapes is the assumption that we can shape our surroundings - and our experience of them - according to our ideals. However, as the ethnographic account above illustrates, the design of places in the age of the Anthropocene must take into account that we do not only shape the world willingly but also unwillingly.

\section{CONCLUSION}

In this article I have explored placemaking processes in two new residential complexes stressing that not only their built environment, but also their identity, story, city-life and social life can be considered as matters of design. Architecture, mediated communication, branding, various design techniques and social processes like gentrification blend together in the strategic shaping of the two places. They can both be described as over-designed, but in two different ways: In the A-house the architect shaped everything from rooftop terrace to doorhandles, but due to the economic crisis the overall function and concept of the house was changed several times along the way. In the 8-house, on the contrary, the change was rather in finish and building materials, whereas the overall concept and functions of the house were maintained. In both cases, the notion of over-designed also refers to the various attempts at shaping and staging the life and aura of the place, even designing an element of something undesigned to invoke a unique spirit of place: the mountain village or the creative past. Though these over-designed places hold such longing for an undesigned friction, the friction that shapes their form and life derives from the vicissitudes of the market, man-made yet beyond control.

Through the notion of brandscapes I have discussed how designed places work as icons for social identity and community building. As we have seen in the 8 -house, residents adopt and move into a story and 
a brand as much as a built complex, whereas the original concept of loft living in the A-house tends to collide more with the current use. Brandscapes may provide iconic identity units, but as a placemaking strategy they are vulnerable to changing circumstances. There are several reasons that "who we are" and "how we feel" are not easily designed: Users appropriate and alter places and stories in their own ways while fluctuations in the economy leave remarkable traces in the material and social fabric of the designed places. Places and people end up being quite different from the prefabricated images. Furthermore, urban design fashions change faster than buildings and urban environments are constructed, meaning that the visions and ideals captured in brands and buildings are often overtaken by new developments. The over-designed thus turns out to be undesigned in unforeseen ways.

\section{NOTES}

1. The fieldwork was conducted in JanuaryAugust 2012 and consisted of qualitative interviews, participant observation and gathering of relevant documents, press coverage etc. The interviews were with professionals involved in shaping the places: building owners, developers, planners, architects, designers, real estate dealers as well as with residents and other users. Furthermore, I took residence for one month in a flat in the A-House and the 8-house respectively in order to conduct participant observation in the everyday use and place-making post occupancy.

2. My translation. Interview "Kosmopolitisk kollektiv" in Magasinet KBH, 24 March, 2010.

3. My translation. Retrieved from: http://www.8tallet.dk/om8tallet.html (visited June 2014).

4. In Danish: “Nu har vi både kro og købmand i bjerglandsbyen".

5. Retrieved from: http://staycopenhagen.dk/ stay-informed/stay-then/(visited June 2014)

6. The A-shape of course derives from the original building that was designed long before Google Earth. My point is, however, that the dawn of technologies like Google Earth as well as the increasing focus on iconic architecture prompt the fusion of architecture and graphic design. The building's A-shape is for instance reproduced on the cover of the coffee-table book about the creative past and in A-shaped door hangers saying "Please STAY away" (instead of the usual phrase used in hotels: "Do not disturb").

\section{REFERENCES:}

De Certeau, Michel. (1990). The practice of everyday life. Berkeley and Los Angeles: University of California Press.

Florida, Richard. (2002). The rise of the creative class. And how it's transforming work, leisure, community, \& everyday life. New York: Basic Books.

Haythornthwaite, Caroline. (2007). Social networks and online community. In Adam N. Joinson. (2007). The Oxford handbook of Internet psychology (pp. 121-138). Oxford: Oxford University Press.

Klingmann, Anna. (2007). Brandscapes. Architecture in the experience economy. Cambridge, Massachusetts: MIT Press.

Latour, Bruno. (2009). Spheres and Networks: Two ways to reinterpret globalization, Harvard Design Magazine, 30, Spring/ summer.

Latour, Bruno. (2011, November). Waiting for Gaia. Composing the common world through arts and politics. A lecture at the French Institute, London.

Löfgren, Orvar. (2007). First we take Manhattan, then we take Berlin. In Gitte Marling \& Martin Zerlang (Eds.): Fun City. København: Arkitektens Forlag.

Oxford Dictionaries. (2015). brand. Oxford: Oxford University Press. Retrieved from: http://www.oxforddictionaries.com/ definition/american english/brand

Skovmand, Thomas Aagaard. (Ed.). (2011). Slipset - en bog om Ørestad. Af beboerne i Ørestad med flere... København: Byens.

Stender, Marie. (2006). Om at bo i glashus. En antropologisk analyse af rum, synliggørelser og beboelsespraksisser i københavnske boliger og arbejdspladser med transparent arkitektur. [MA Thesis]. Institut for Antropologi, Københavns Universitet: specialerække 394.

Willim, Robert. (2005). It's in the mix: Configuring industrial cool. In Orvar Löfgren \& Robert Willim (Eds.): Magic, culture and the new economy. Oxford \& New York: Berg.

Zukin, Sharon. (1989). Loft living: Culture and capital in urban change. New York: John Hopkins University Press.

\section{CORRESPONDENCE}

Marie Stender

Aalborg University

Town, housing and property

A.C. Meyers Vænge 15

2450 København SV

Denmark

E-mail: mas@sbi.aau.dk

Published online 28 July, 2015

ISSN 1749-3463 print/ISSN 1749-3471

http://dx.doi.org/10.14434/artifact.v3i4.5124

(C) 2015 Artifact 